SALAM; Jurnal Sosial \& Budaya Syar-i

FSH UIN Syarif Hidayatullah Jakarta

Vol. 5 No. 3 (2018), pp.291-306, DOI: 10.15408/sjsbs.v5i3.10366

\title{
Hoaks Dalam Kajian Pemikiran Islam dan Hukum Positif
}

(Hoax in Islamic Thinking and Positive Law Studies)

\author{
Supriyadi Ahmad, ${ }^{1}$ Husnul Hotimah ${ }^{2}$ \\ Universitas Islam Negeri Syarif Hidayatullah, Jakarta, Indonesia \\ doi) $10.15408 /$ sjsbs.v5i3.10366
}

\begin{abstract}
:
Hoax originating from "focus pocus" originally from Latin "hoc est corpus", means false news. Hoax also comes from English, namely Hoax, which means fake news. Terminologically, hoax is a false message in an attempt to deceive or influence readers or dealers to believe something, even though the source of the news delivered is completely baseless. Ahead of the Legislative and Presidential Elections in Indonesia 2019, hoax have entered the political sphere which can threaten the nation's unity and unity. In the perspective of Islamic thought, hoax is a public lie or dissemination of information that is misleading and even defame the other party. The hoax maker is classified as a party that harms others and the hoaxes made are categorized as ifki hadith or false news. Therefore, the perpetrators were threatened with very severe torture. In a positive legal perspective, hoax is a charge of false and misleading news, a content that creates hatred or hostility of certain individuals and/or groups based on ethnicity, religion, race, and between groups (SARA). The culprit can be punished with a maximum of ten years in prison.
\end{abstract}

Keywords: Hoax, Islamic Studies, Positive Law.

\begin{abstract}
Abstrak:
Hoaks yang berasal dari "hocus pocus" a slinya dari bahasa Latin "hoc est corpus", berarti berita bohong. Hoaks juga berasal dari Bahasa Inggris Hoax, yang berarti berita palsu. Secara terminologis, hoaks merupakan sebuah pemberitaan palsu dalam usaha untuk menipu atau mempengaruhi pembaca atau pengedar untuk mempercayai sesuatu, padahal sumber berita yang disampaikan adalah palsu tidak berdasar sama sekali. Menjelang Pemilu Legislatif dan Pemilu Presiden di Indonesia tahun 2019, hoaks telah memasuki ranah politik yang dapat mengancam persatuan dan kesatuan bangsa. Dalam perspektif pemikiran Islam, hoaks adalah pembohongan publik atau penyebaran informasi yang menyesatkan dan bahkan menistakan pihak lain. Pembuat hoaks digolongkan sebagai pihak yang merugikan orang lain dan hoaks yang dibuatnya dikategorikan sebagai haditsul ifki atau berita bohong. Oleh karena itu, penyebarnya diancam dengan siksa yang sangat berat. Dalam perspektif hukum Positif, hoaks merupakan muatan berita bohong dan menyesatkan, muatan yang menimbulkan rasa kebencian atau permusuhan individu dan/atau kelompok masyarakat tertentu berdasarkan atas suku, agama, ras, dan antar golongan (SARA). Pelakunya dapat dihukum dengan penjara setinggitingginya sepuluh tahun.
\end{abstract}

Kata Kunci: Hoaks, Kajian Islam, Hukum Positif.

*Diterima: 20 September 2018, Revisi: 21 Oktober 2018, Dipublikasi 11 Desember 2018.

1 Penulis pertama adalah Dosen Tetap Fakultas Syariah dan Hukum, UIN Syarif Hidayatullah Jakarta. Email: supriyadi.ahmad@uinjkt.ac.id.

2 Penulis kedua adalah alumni Program Studi Perbandingan Madzhab, Fakultas Syariah dan Hukum UIN Syarif Hidayatullah Jakarta. E-mail: hotimah.husnul0910@gmail.com. 


\section{Pendahuluan}

Menjelang pemilihan legislatif (Pileg) dan Pemilihan Presiden (Pilpres) yang akan dilaksanakan tanggal 17 April 2019 muncul berbagai isu politik dan isu-isu social lainnya yang dapat mengusik ketenangan masyarakat. Isu tentang tujuh container surat suara yang tercoblos, ${ }^{3}$ misalnya, telah menjadi perhatian serius pihak berwajib. Bukan hanya sampai di situ. Ternyata motif pembuat hoaks, adalah beragam. Dari perbuatan iseng hingga menyudutkan pemimpin bangsa. ${ }^{4}$ Dari sumber lain didapatkan legitimasi tentang bahaya hoaks tersebut. Misalnya Syamsuddin Haris, seorang pengamat politik dari Lembaga Ilmu Pengetahuan Indonesia (LIPI) menyatakan, hoaks sejenis dengan sejenis dengan tujuh container surat suara tercoblos patut diwaspadai. Sebab hoaks ini sudah mengenai hal yang paling penting dari pemilu, yaitu surat suara. Karena surat suara itu, ${ }^{5}$ menurut Haris, adalah jantungnya pemilu. Kalah atau menangnya seorang Calon Legislatif atau Presiden, dihitung dari surat suara.

Tampaknya hoaks semakin brutal. Perang melawan hoaks tidak lagi soal akal sehat, tetapi juga terkait dengan kecanggihan teknologi, ketegasan hukum, dan kecerdasan para aparat penegak hukum. ${ }^{6}$ Selain itu, menurut penulis editorial Harian Media Indonesia, Hoak bukan lagi diproduksi dengan memelintir fakta, tetapi juga sudah diproduksi berdasarkan sesuatu yang tidak sama sekali ada. Pemainnya bukan hanya kelas teri, tetapi juga melibatkan pejabat partai. Oleh karena itu, kajian mendalam dan komprehensif terhadap hoaks dan bahayanya dalam perspektif pemikiran Islam dan Hukum Positif menjadi sangat penting.

\section{Epistemologi Hoaks}

Hoaks menurut Kamus Besar Bahasa Indonesia Dalam Jaringan (KBBI Daring) berarti berita bohong.7 Kata Hoaks berasal dari "hocus pocus" yang aslinya adalah bahasa latin "hoc est corpus", artinya "ini adalah tubuh". Kata ini biasa digunakan penyihir untuk mengklaim bahwa sesuatu adalah benar, padahal belum tentu benar. Hoaks juga banyak beredar di email, milis, BBM, dan lain-lain. Hoaks juga merupakan sebuah pemberitaan palsu dalam usaha untuk menipu atau mempengaruhi pembaca atau pengedar untuk mempercayai

3 Arif Sario Nugroho dan Fauziah Mursid, "Polisi Dalami Motif Hoaks Tujuh Kontainer", dalam Harian Republika, Kamis, 10 Januari 2019, hal. 1.

4 Putri Rosmalia Octaviyani, "Pembuat Hoaks Ingin Sudutkan Jokowi", dalam Harian Media Indonesia, Kamis, 10 Januari 2019, hal. 1.

${ }^{5}$ Inas Widyanuratikah, "Pengamat: Hoaks Soal Pemilu Berbahaya", dalam Harian Republika, Jumat, 11 Januari 2019, hal. 9.

${ }^{6}$ Abdul Kahar, "Perang Melawan Hoaks", dalam Editorial Harian Media Indonesia, Kamis, 10 Januari 2019, hal. 2.

${ }^{7}$ Lihat selengkapnya di website: $\underline{\text { https://kbbi.kemdikbud.go.id/entri/HOAKS }}$ 
sesuatu, padahal sumber berita mengetahui bahwa bertita yang disampaikan adalah palsu tidak berdasar sama sekali. ${ }^{8}$

Kata Hoaks berasal dari bahasa Inggris yang artinya tipuan, menipu, berita bohong, berita palsu, dan kabar burung. Jadi, Hoaks dapat diartikan sebagai ketidakbenaran suatu informasi. Menurut Wikipedia, Hoaks merupakan sebuah pemberitaan palsu yakni sebuah usaha untuk menipu atau mengakali pembaca dan pendengar agar mempercayai sesuatu. ${ }^{9}$

Dalam Undang-Undang Nomor 19 Tahun 2016 tentang Perubahan Atas Undang-Undang Nomor 11 Tahun 2008 Tentang Informasi dan Transaksi Elektronik tersebut diatur tentang penyebaran berita bohong (hoaks) bagi yang melanggardapat dikenakan sanksi berikut: Pasal 45 A ayat (1) yaitu muatan berita bohong dan menyesatkan, Pasal 45 A ayat (2) yaitu muatan yang menimbulkan rasa kebencian atau permusuhan individu dan/atau kelompok masyarakat tertentu berdasarkan atas suku, agama, ras, dan antar golongan (SARA). ${ }^{10}$

Istilah berita bohong (hoaks) dalam Alquran bisa diidentifikasi dari pengertian kata al-Ifk yang berarti keterbalikan (seperti gempa yang membalikkan negeri), tetapi yang dimaksud di sini ialah sebuah kebohongan besar, karena kebohongan adalah pemutarbalikan fakta. Sedangkan munculnya hoaks (sebuah kebohongan) disebabkan oleh orang-orang pembangkang. ${ }^{11}$

Kata al-ifk dalam berbagai bentuknya disebutkan sebanyak 22 kali dalam Al-Qur'ean. Kata al-ifk digunakan dalam Alquran untuk arti sebagai berikut:

1. Perkataan dusta, yakni perkataan yang tidak sesuai dengan kenyataan. Ia disebutkan dalam kasus isteri Rasulullah saw., Aisyah ra. (QS. al-Nur/24: 11).

2. Kehancuran suatu negeri karena penduduknya tidak membenarkan ayat-ayat Allah, misalnya QS. al-Tawbah (9): 70.

3. Dipalingkan dari kebenaran karena mereka selalu berdusta, seperti QS. al-Ankabut (29): 61. ${ }^{12}$

\footnotetext{
${ }^{8}$ Muhammad Arsad Nasution. "Hoaks Sebagai Bentuk Hudud Menurut Hukum Islam", Jurnal Yurisprudentia, III, (2017), hal. 17.

9 Adami Chazawi dan Ferdian Ardi, Tindak Pidana Pemalsuan II, (Jakarta: PT Rajagrafindo Persada, 2016), hal. 236.

${ }^{10}$ Undang-Undang Nomor 19 Tahun 2016 atas perubahan Undang-Undang No 11 Tahun 2008 Tentang Informasi dan Transaksi Elektronik.

11 M.Quraish Shihab. "Tafsir Al-Misbah: Pesan, Kesan dan Keserasian Al-Quran, IX, (Jakarta: Lentera Hati, 2002), hal. 296.

12 Fauzi Damrah, "Ifk" h. Dalam Sahabuddin et al (ed.), Jurnal Ensiklopedia Al-Qur'an, I, (2007), hal. 342.
} 
Kasus hoaks yang terjadi misalnya yang menimpa seorang penulis, narablog, dan pengusaha yang dikenal karena usaha self publishing dapurbuku.com yaitu Jonru Ginting. Jonru terbukti melanggar Pasal 28 ayat 2 Juncto Pasal 45A ayat 2 Undang-Undang Nomor 19 Tahun 2016 tentang Perubahan atas Undang-Undang RI Nomor 11 Tahun 2008 tentang Informasi dan Transaksi Elektronik juncto Pasal 65 ayat 1 KUHP.

Jaksa juga menyebut serangkaian informasi yang disebut menimbulkan kebencian itu diunggah Jonru dalam akun Facebook miliknya. Menurut jaksa juga, hal-hal yang memberatkan ialah terdakwa tidak merasa bersalah dan menyesali perbuatannya serta perkara ini menarik perhatian masyarakat. Sedangkan hal yang meringankan adalah terdakwa merupakan tulang punggung keluarga dan belum pernah dihukum.

Jonru juga dikenakan pasal berlapis Pertama, Pasal 28 ayat (2) juncto Pasal 45A ayat (2) Undang-Undang Nomor 19 tahun 2016 tentang Perubahan atas UU RI Nomor 11 tahun 2008 tentang Informasi dan Transaksi Elektronik (UU ITE). Dakwaan kedua untuk Jonru adalah Pasal 4 huruf b angka 1 juncto Pasal 16 Undang-Undang Nomor 40 tahun 2008 tentang Penghapusan Diskriminasi Ras dan Etnis. Dan dakwaan ketiga adalah Pasal 156 KUHP. ${ }^{13}$

Kasus selanjutnya yaitu menimpa Buni Yani seorang peneliti dari Universitas Leiden, Belanda. Yang mengunggah video viral pidato mantan Gubernur Dki Jakarta, Basuki Tjahaja Purnama (Ahok). Di dalam video tersebut terdakwa menghilangkan kata "pakai" sedangkan yang diucapkan oleh Ahok itu menggunakan kata "pakai", sehingga seakan-akan Ahok mengatakan dibohongi Al-Maidah. ${ }^{14}$

\section{Informasi yang Benar Versus Hoaks}

Perkembangan teknologi informasi termasuk internet didalamnya juga memberikan tantangan tersendiri bagi perkembangan hukum di Indonesia. Hukum di Indonesia juga dituntut untuk dapat menyesuaikan dengan perubahan sosial yang terjadi. Perubahan-perubahan sosial dan perubahan hukum atau sebaliknya tidak selalu berlangsung bersama-sama. Artinya pada keadaan tertentu perkembangan hukum mungkin tertinggal oleh

${ }^{13}$ wartakota.tribunnews.com, "Buni Yani Sempat Mengaku Telah Memotong Kata "Pakai" dalam Transkrip Pidato Ahok". Artikel diakses pada 02 Juli 2018. https://liputan6.com > News > Peristiwa "Ini Postingan Jonru Ginting yang Berujung Tersangka."

${ }^{14}$ wartakota.tribunnews.com, "Buni Yani Sempat Mengaku Telah Memotong Kata "Pakai" dalam Transkrip Pidato Ahok". Artikel diakses pada 04 Juli 2018. 
perkembangan unsur-unsur lainnya dari masyarakat serta kebudayaannya atau mungkin hal yang sebaliknya. ${ }^{15}$

Pengertian informasi juga menggunakan definisi dari Undang-Undang No 14 Tahun 2008. Terkait dengan mutu informasi, Buckland menjabarkan informasi menjadi: a) information-as-process (berperan menyampaikan), b) information-as-knowledge (sesuatu yang dirasakan dalam information-as- process, pengetahuan yang dikomunikasikan), dan, c) information-as-thing, informasi adalah objek, seperti data dan dokumen yang dapat memberikan informasi.

Individu sebagai pengguna tentu mengharapkan informasi yang akurat. Informasi harus sesuai dengan kenyataan. Keandalan suatu informasi meningkat apabila informasi tersebut dapat diverifikasi, yakni kebenarannya dapat dibuktikan secara independen. Informasi harus cukup up-to-date. Sesuai dengan maksud penggunaannya, informasi harus lengkap dan tepat sehingga pihak yang menerima dapat memilih perincian spesifik yang sesuai dengan kebutuhannya. Informasi harus bermakna jelas, yakni dapat dimengerti oleh si penerima. ${ }^{16}$

Teori informasi berkembang sejak tumbuhnya industri telekomunikasi setelah perang Dunia Ke II, merupakan area kajian komunikasi dalam sistem. Perspektif ini berfokus pada pengukuran informasi. Teori ini membahas kajian kuantitatif dari informasi dalam pesan dan arus informasi dikirim dari sender ke receiver. Informasi merupakan ukuran ketidakpastian atau situasi entropy dalam sebuah situasi atau disebut juga dengan redundancy. Semakin besar ketidakpastian, semakin besar informasi dibutuhkan. Informasi merupakan sebuah fungsi dari sejumlah alternatif. Ini mencerminkan derajat kebebasan dalam membuat pilihan dalam sebuah situasi. ${ }^{17}$

Peredaran berita hoaks di media sosial semakin marak. Kita sebagai warganet, tentu harus cerdas memilah mana informasi yang asli, serta informasi mana yang dikategorikan berita bohong. Pasalnya, jika berita bohong dibiarkan mewabah, keberadaannya jelas mengancam masyarakat karena menebar informasi yang tidak benar. Mirisnya lagi, kita belum punya cara pasti untuk bisa membedakan jenis informasi mana yang akurat dan yang hoaks. ${ }^{18}$

${ }^{15}$ Merry Magdalena dan Maswigrantoron Roes Setyadi. "Cyber Law Tidak Perlu Takut", (Yogyakarta: Andi, 2007), hal. 59.

${ }^{16}$ Rivalina, R a h m i, "Pola Pencarian Informasi di Internet", Jurnal Teknologi Pendidikan (14), VII, (2004), hal. 199-216

${ }^{17}$ Armawati Arbi, Dakwah dan Komunikasi. (Tangerang Selatan: UIN Jakarta Press, 2014), hal. 67.

${ }^{18}$ Artikel diakses tanggal 20 Juli 2018 dari http://www.liputan6.com Asli atau Hoaks? Cek Keaslian Berita dengan 4 Cara ini 
Tips membedakan berita asli atau hoaks dari Praktisi Anti Hoaks dan Alumnus TI ITB Dimas Fathroen pada Liputan 6 tentang cek keaslian berita dengan 4 cara ini, diantaranya adalah:

1. Elemen Berita Hoaks: Pastikan berita yang kamu baca tidak memiliki kalimat-kalimat yang janggal, seolah persuasif dan memaksa seperti: -Sebarkanlah! -Viralkanlah! dan sejenisnya. Artikel penuh huruf besar dan tanda seru pun disinyalir mengandung infromasi hoaks. Biasanya juga merujuk pada kejadian yang tidak ada tanggal dan harinya, dan tak jarang juga mengklaim sumbernya berasal dari sumber yang tidak terpercaya.

2. Verifikasi Sumber: Pastikan kamu verifikasi sumber dan konten berita dengan mencarinya di Google. Cari tema berita secara spesifik dengan kata hoaks dibelakangnya. Biasanya, kalau memang benar itu hoaks, akan muncul artikel pembahasan terkait.

3. Cek Gambar dan Cek dengan Aplikasi: Kamu dapat memastikan sumber dari foto yang diunggah di artikel berita terkait. Jadi, kamu bisa mengecek aplikasi khusus bernama Hoaks Analyzer. ${ }^{19}$

\section{Aksiologi Informasi yang Benar}

Peranan teknologi informasi dan komunikasi di era globalisasi telah menempatkan pada posisi yang amat strategis karena menghadirkan suatu dunia tanpa batas, jarak, ruang, dan waktu, yang berdampak pada peningkatan produktivitas dan efisiensi. Pengaruh globalisasi dengan penggunaan sarana teknologi informasi dan komunikasi telah mengubah pola hidup masyarakat, dan berkembang dalam tatanan kehidupan baru dan mendorong terjadinya perubahan sosial, ekonomi, budaya, pertahanan, keamanan, dan penegakan hukum..$^{20}$

Teknologi informasi dan komunikasi dewasa ini, telah dimanfaatkan dalam kehidupan sosial masyarakat, dan telah memasuki berbagai sektor kehidupan baik sektor pemerintah, sector bisnis, perbankan, pendidikan, kesehatan, dan kehidupan pribadi. Manfaat teknologi informasi dan komunikasi selain memberikan dampak positif juga disadari memberi peluang untuk dijadikan sarana melakukan tindak kejahatan-kejahatan baru (cyber crime) sehingga diperlukan upaya proteksi. Sehingga dapat dikatakan bahwa teknologi informasi dan komunikasi bagaikan pedang bermata dua, di mana selain memberikan kontribusi positif bagi peningkatan kesejahteraan kemajuan, dan

${ }^{19}$ Sunarso, Siswanto, Hukum Informasi dan Transaksi Elektronik. (Jakarta: PT. Rineka Cipta, 2009), hal. 39.

${ }^{20}$ Sunarso, Siswanto, Hukum Informasi dan Transaksi Elektronik. (Jakarta: PT. Rineka Cipta, 2009), hal. 39 
peradaban manusia, juga menjadi sarana potensial dan sarana efektif untuk melakukan perbuatan melawan hukum. ${ }^{21}$

Perbuatan melawan hukum di dunia maya merupakan fenomena yang sangat mengkhawatirkan, mengingat tindakan caeding, hcking, penipuan, terorisme, dan penyebaran informasi destruktif telah menjadi bagian dari aktivitas pelaku kejahatan di dunia maya. Kenyataan itu, demikian sangat kontras dengan ketiadaan regulasi yang mengatur pemanfaatan teknologi informasi dan komunikasi di berbagai sector dimaksud. Oleh karena itu, untuk menjamin kepastian hukum, pemerintah berkewajiban melakukan regulasi terhadap berbagai aktivitas terkait dengan pemanfaatan teknologi informasi dan komunikasi tersebut.

Undang-Undang RI Nomor 11 tahun 2008 yang telah diubah menjadi Undang-Undang Nomor 19 Tahun 2016 tentang Informasi dan Transaksi Elektronik adalah wujud dari tanggung jawab yang harus diemban oleh Negara, untuk memberikan perlindungan maksimal pada seluruh aktivitas pemanfaatan teknologi informasi dan komunikasi di dalam negeri agar terlindungi dengan baik dari potensi kejahatan dan penyalahgunaan teknologi. Dalam konsideran UU Nomor 11 tahun 2008 yang telah diubah menjadi Undang-Undang Nomor 19 Tahun 2016 tentang ITE, dinyatakan bahwa pembangunan nasional yang telaah dilaksanakan pemerintah Indonesia dimulai pada era orde baru hingga orde saat ini, merupakan proses yang berkelanjutan yang harus senantiasa tanggap terhadap berbagai dinamika yang terjadi di masyarakat. Dinamika kehidupan masyarakat itu, akibat pengaruh globalisasi informasi, telah menempatkan Indonesia sebagai bagian dari masyarakat informasi dan transaksi elektronik di tingkat nasional sehingga pembangunan teknologi informasi dapat dilakukan secara optimal, merata, dan menyebar keseluruh lapisan masyarakat guna mencerdaskan kehidupan bangsa. 22

Demikian pesatnya perkembangan dan kemajuan teknologi informasi, yang merupakan salah satu penyebab perubahan kegiatan kehidupan manusia dalam berbagai bidang yang secara langsung telah mempengaruhi lahirnya bentuk-bentuk perbuatan hukum baru. Penggunaan dan pemanfaatan teknologi informasi harus terus dikembangkan untuk menjaga, memelihara, dan memperkukuh persatuan dan kesatuan nasional berdasarkan peraturan perundang-undangan demi kepentingan nasional.

Di samping itu, pemanfaatan teknologi informasi berperan penting dalam perdagangan dan pertumbuhan perekonomian nasioanl untuk mewujudkan kesejahteraan masyarakat. ${ }^{23}$ berdasarkan hal itulah, pemerintah

\footnotetext{
${ }^{21}$ Sunarso, Siswanto, Hukum Informasi dan Transaksi Elektronik, hal. 40

22 Sunarso, Siswanto, Hukum Informasi dan Transaksi Elektronik. Hal. 41.

${ }^{23}$ Diakses pada 27 Juli 2018 dari https://www.researchgate.net/publication/
} 
perlu mendukung perkembangan teknologi informasi melalui infrastruktur hukum dan pengaturannya, sehingga pemanfaatan teknologi informasi dilakukan secara aman, untuk mencegah penyalahgunaannya dengan memperhatikan nilai-nilai agama dan sosial budaya masyarakat Indonesia.

Perkembangan dan pemanfaatan teknologi informasi, media, dan komunikasi telah mengubah baik perilaku masyarakat maupun peradaban manusia secara global. Perkembangan tersebut telah melahirkan suatu rezim hukum baru, yang dikenal dengan hukum siber atau telematika. Hukum siber atau cyber law secara internasional digunakan untuk istilah hukum yang terkait dengan pemanfaatan teknologi informasi dan komunikasi. ${ }^{24}$

\section{Hoaks Dalam Perspektif Pemikiran Islam}

Hoaks sebagai bentuk pembohongan terhadap publik merupakan perbuatan yang tidak dibenarkan dalam Islam. Segala jenis pembohongan baik pembohongan yang ditujukan untuk individu maupun pembohongan terhadap lembaga, organisasi, atau terhadap sekelompok masyarakat yang bertujuan untuk membentuk opini publik atau propokasi serta kepentingan politik adalah perbuatan terlarang menurut kajian Islam. Pembuat hoaks digolongkan sebagai pihak yang merugikan orang lain dan hoaks yang dibuatnya dikategoriman sebagai haditsul ifki atau berita bohong.

Pada ayat al-Quran Allah Swt menjelaskan:

"Sesungguhnya orang-orang yang membawa berita bohong itu adalah dari golongan kamu juga. janganlah kamu kira bahwa berita bohong itu buruk bagi kamu bahkan ia adalah baik bagi kamu. tiap-tiap seseorang dari mereka mendapat Balasan dari dosa yang dikerjakannya. dan siapa di antara mereka yang mengambil bahagian yang terbesar dalam penyiaran berita bohong itu baginya azab yang besar." 25

276108971_Pemanfaatan_Teknologi_Infor-asi_dalam_Pengembangan_Bisnis_Pos

24 Budi Suhariyanto, Tindak Pidana Informasi (cyber crime). (Depok: Raja Grafindo Persada, 2013), cet. II, hal. 30

${ }^{25}$ Selengkapnya lihat Tafsir Alquran, Kementerian Agama, 2003 yang dijelaskan sebagai berikut: Berita bohong (hadits al-ifk) ini mengenai istri Rasulullah s.a.w. 'Aisyah r.a. Ummul Mu'minin, sehabis perang dengan Bani Mushtaliq bulan Sya'ban 5 H. Perperangan ini diikuti oleh kaum munafik, dan turut pula 'Aisyah dengan Nabi berdasarkan undian yang diadakan antara istri-istri beliau. dalam perjalanan mereka kembali dari peperangan, mereka berhenti pada suatu tempat. 'Aisyah keluar dari sekedupnya untuk suatu keperluan, kemudian kembali. tiba-tiba Dia merasa kalungnya hilang, lalu Dia pergi lagi mencarinya. Sementara itu, rombongan berangkat dengan persangkaan bahwa 'Aisyah masih ada dalam sekedup. setelah 'Aisyah mengetahui, sekedupnya sudah berangkat Dia duduk di tempatnya dan mengaharapkan sekedup itu akan kembali menjemputnya. Kebetulan, lewat ditempat itu seorang sahabat Nabi, Shafwan Ibnu Mu'aththal, diketemukannya seseorang sedang tidur sendirian dan Dia terkejut seraya mengucapkan: "Inna lillahi wa inna ilaihi raji'un, isteri Rasul!" 'Aisyah terbangun. lalu Dia 
"Mengapa di waktu kamu mendengar berita bohon itu orang-orang mukminin dan mukminat tidak bersangka baik terhadap diri mereka sendiri, dan (mengapa tidak) berkata: "Ini adalah suatu berita bohong yang nyata." (Q.S. AnNur 11 - 12).

Selanjutnya Alquran juga melarang penyebaran hoaks atau berita bohong, seperti halnya hadits al-ifk, dan Allah mengancam bahwa penyebarnya akan mendapat siksa yang amat pedih. Inilah dirilis olah Alquran dalam Surat An-Nur ayat 19 berikut ini:

Sesungguhnya orang-orang yang ingin agar (berita) perbuatan yang amat keji itu tersiar di kalangan orang-orang yang beriman, bagi mereka azab yang pedih di dunia dan di akhirat. dan Allah mengetahui, sedang, kamu tidak mengetahui. (Q.S. An-Nur: 19).

Dengan demikian, informasi yang disebarkan oleh seseorang harus benar dan akurat. Keakuratan informasi dalam komunikasi massa juga bisa dilihat dari sejauhmana informasi tersebut telah dengan cermat dan seksama, sehingga informasi yang disajikan telah mencapai ketepatan. ${ }^{26}$ Menyampaikan informasi secara tepat merupakan landasan pokok untuk tidak mengakibatkan masyarakat pembaca, pendengar, dan pemirsa mengalami kesalahan. Kesalahan yang ditimbulkan oleh kesesatan informasi pada media massa, tentu bisa diperkirakan betapa besar bahaya dan kerugian yang diderita masyarakat banyak. ${ }^{27}$

Untuk mencapai ketepatan data dan fakta sebagai bahan informasi yang akan disampaikan kepada masyarakat diperlukan penelitian yang seksama oleh kalangan Pers, terutama wartawan. Ajaran Is la m mengakomodasikan etika akurasi informasi tersebut melalui tabayyun. Kata tabayyun disebutkan sebanyak dua kali dalam surat al-Nisa/4: 94, dan satu kali pada surat alHujurat/49: 6.

"Hai orang-orang yang beriman, apabila kamu pergi (berperang) di jalan Allah, Maka telitilah dan janganlah kamu mengatakan kepada orang yang mengucapkan "salam" kepadamu: "Kamu bukan seorang mukmin" (lalu kamu membunuhnya), dengan maksud mencari harta benda kehidupan di dunia, karena di sisi Allah ada harta yang banyak. begitu jugalah Keadaan kamu dahulu, lalu Allah menganugerahkan nikmat-Nya atas kamu, Maka telitilah. Sesungguhnya Allah Maha mengetahui apa yang kamu kerjakan." (Q.S. AnNisa': 94).

dipersilahkan oleh Shafwan mengendarai untanya. Syafwan berjalan menuntun unta sampai mereka tiba di Madinah. orang-orang yang melihat mereka membicarakannya menurut Pendapat masing-masing. mulailah timbul desas-desus. kemudian kaum munafik membesar- besarkannya, Maka fitnahan atas 'Aisyah r.a. itupun bertambah luas, sehingga menimbulkan kegoncangan di kalangan kaum muslimin.

${ }^{26}$ Mafri Amir, Etika Komunikasi Massa. (Jakarta: PT. Logos Wacana Ilmu), hal.90.

${ }^{27}$ Mafri Amir, Etika Komunikasi Massa, hal.91 
Dalam Surat al-Hujurat/49:6, Allah berfirman:

“Hai orang-orang yang beriman, jika datang kepadamu orang Fasik membawa suatu berita, Maka periksalah dengan teliti agar kamu tidak menimpakan suatu musibah kepada suatu kaum tanpa mengetahui keadaannya yang menyebabkan kamu menyesal atas perbuatanmu itu." (Q.S. Al-Hujurat: 6).

Dalam ayat ini, Allah memberikan peringatan kepada kaum Mukminin, jika datang kepada mereka seorang fasik membawa berita tentang apa saja, agar tidak tergesa-gesa menerima berita itu sebelum diperiksa dan diteliti dahulu kebenarannya. Sebelum diadakan penelitian yang seksama atau konfirmasi atau verifikasi, jangan cepat percaya kepada berita dari orang fasik, karena seorang yang tidak mempedulikan kefasikannya, pasti tidak akan mempedulikan kedustaan berita yang disampaikannya..$^{28}$

Pada ayat ini terdapat petunjuk dalam menerima informasi seseorang, bisa diterima kalau ia adil, karena perintah dalam ayat agar bersikap hati-hati ketika menerima kabar dari oramg fasiq. Sebab orang fasiq sebetulnya tidak bisa diterima informasinya. Informasi itu merupakan kepercayaan, dan kefasikan merupakan indikator hilangnya kepercayaan.

\section{Hoaks Dalam Perspektif Hukum Positif}

Ketentuan tentang penyebaran berita bohong atau hoaks yang dapat menimbulkan keonaran diatur dalam dua ketentuan melalui UndangUndang Nomor 1 Tahun 1946 tentang Hukum Pidana. Pasal 14 UndangUndang a quo menegaskan: ayat 1 "barangsiapa, dengan menyiarkan berita atau pemberitahuan bohong, dengan sengaja menerbitkan keonaran dikalangan rakyat, dihukum dengan penjara setinggi- tingginya sepuluh tahun; ayat 2 "barangsiapa mengeluarkan pemberitahuan yang dapat menerbitkan keonaran dikalangan rakyat, sedangkan dia patut dapat menyangka bahwa berita atau pemberitahuan itu bohong, dihukum dengan penjara setinggi-tingginya tiga tahun. $^{29}$

Nilai pembeda dari dua ketentuan diatas, yaitu pada ayat kesatu merupakan perbuatan menyebarkan berita bohong akan menimbulkan keonaran karena kesengajaan sebagai maksud atau kepastian. Artinya si pembuat pidana jelas-jelas memiliki kehendak dan pengetahuan kalau perbuatan menyebarkan berita kebohongan itu akan menimbulkan keonaran.

${ }^{28}$ Al-Quran dan Tafsir, Kementrian Agama Republik Indonesia, 2003.

${ }^{29}$ Nur Aisyah Siddiq, "Penegakan Hukum Pidana Dalam Penanggulangan Berita Palsu (Hoaks) Menurut Undang-Undang No.11 Tahun 2008 Yang Telah Dirubah Menjadi UndangUndang No.19 Tahun 2016 Tentang Informasi Dan Transaksi Elektronik" Dalam Jurnal Lex Et Societatis Vol. V/No. 10/Des/2017, hal. 27 
Sedangkan pada ayat keduanya, merupakan perbuatan sebagai kesengajaan akan kemungkinan, bahwa kepadanya patut mengetahui atau patut menduga kalau dari pada perbuatan menyebarkan berita kebohongan akan menimbulkan keonaran.

Soal kekaburan makna apa yang dimaksud "keonaran" dalam pasal a quo, telah dijelaskan dalam ketentuannya lebih lanjut bahwa, keonaran adalah lebih hebat dari pada kegelisahan dan menggoncangkan hati penduduk yang tidak sedikit jumlahnya. ${ }^{30}$

Dengan memperhatikan ketentuan ini, kiranya perbuatan salah satu nitizen beberapa bulan lalu yang menyebarluaskan informasi palsu soal rush money terkait dengan rencana aksi demonstrasi 25 November 2016, merupakan perbuatan yang telah dapat dikualifikasikan sebagai penyebaran berita bohong yang akan menimbulkan keonaran sebab telah menyebabkan keresahan hati penduduk, khususnya nasabah perbankan.

Selanjutnya, penyebaran berita hoaks yang dapat menimbulkan kebencian terhadap suatu golongan, ketentuannya diatur dalam Pasal 28 ayat 2 UndangUndang Informasi dan Transaksi Elektronik: "Setiap orang dengan sengaja dan tanpa hak menyebarkan informasi yang ditujukan untuk menimbulkan rasa kebencian atau permusuhan individu dan/atau kelompok masyarakat tertentu berdasarkan atas suku, agama, ras, dan antargolongan (SARA),"

Pasal ini pada sesungguhnya tidak memuat unsur "perbuatan kebohongan." Hanya saja, dengan kembali pada peristiwa hukumnya, kerap kali perbuatan kesengajaan menyebarkan informasi yang bertujuan untuk menimbulkan kebencian, konten informasi yang disebarkan biasanya tidak mengandung kebenaran atau sifatnya sebagai berita kebohongan belaka. ${ }^{31}$

Dalam melawan hoaks dan mencegah meluasnya dampak negatif hoaks, pemerintah pada dasarnya telah memiliki payung hukum yang memadai. Pasal 28 ayat 1 dan 2, Pasal 27 ayat 3, Undang-Undang No. 11 tahun 2008 tentang Informasi dan Transaksi Elektronik yang sekarang telah diubah dengan Undang-Undang No.19 tahun 2016, Pasal 14 dan 15 UndangUndang No. 1 tahun 1946, Pasal 311 dan 378

KUHP, serta Undang-Undang No. 40 tahun 2008 tentang Penghapusan Diskiriminasi Ras dan Etnis merupakan beberapa produk hukum yang dapat digunakan untuk memerangi penyebaran hoaks. ${ }^{32}$

Berikut beberapa penjabaran singkat terkait pasal-pasal di dalam Undang- Undang yang mengatur tentang berita palsu atau hoaks :

\footnotetext{
30 Republik Indonesia, "Undang-Undang RI No.1 Tahun 1946 tentang Peraturan Hukum Pidana", Penjelasan Umum, Pasal XIV, hal. 28

31 PAF Lamintang, Delik-delik Khusus, (Bandung: Sinar Baru, 1984), hal. 12

32 PAF Lamintang, Delik-delik Khusus, (Bandung: Sinar Baru, 1984), hal. 12.
} 
a. Pasal 311 KUHP: “jika yang melakukan kejahatan pencemaran atau pencemaran tertulis dibolehkan untuk membuktikan apa yang dituduhkan itu benar, tidak membuktikannya, dan tuduhan dilakukan bertentangan dengan apa yang diketahui, maka dia diancam melakukan fitnah dengan pidana penjara paling lama empat tahun." 33

b. Pasal 378 KUHP: "barang siapa dengan maksud untuk menguntungkan diri sendiri atau orang lain secara melawan hukum, dengan memakai nama palsu atau martabat palsu, dengan tipu muslihat, ataupun rangkaian kebohongan, menggerakkan orang lain untuk menyerahkan barang sesuatu kepadanya, atau supaya memberikan hutang maupun menghapuskan piutang diancam karena penipuan dengan pidana penjara paling lama empat tahun." 6

2. Undang-Undang No.1 Tahun 1946 tentang Peraturan Hukum Pidana

a. Pasal 14 ayat (1) dan (2): Ayat 1 "barangsiapa, dengan menyiarkan berita atau pemberitahuan bohong, dengan sengaja menerbitkan keonaran dikalangan rakyat, dihukum dengan hukuman penjara setinggi-tingginya sepuluh tahun." Ayat 2 "barangsiapa menyiarkan suatu berita atau mengeluarkan suatu pemberitahuan yang dapat menerbitkan keonaran dikalangan rakyat, sedangkan ia patut dapat menyangka bahwa berita atau pemberitahuan itu adalah bohong, dihukum dengan penjara setinggi-tingginya adalah tiga tahun."

b. Pasal 15: "barang siapa menyebarkan kabar yang tidak pasti atau kabar yang berkelebihan atau yang tidak lengkap, sedangkan ia mengerti setidak-tidaknya patut dapat menduga bahwa kabar demikian akan atau sudah dapat menerbitkan keonaran dikalangan rakyat, dihukum dengan hukuman penjara setinggitingginya dua tahun.

3. Undang-Undang No.19 Tahun 2016 tentang Informasi dan Transaksi Elektronik. ${ }^{34} 7$

a. Pasal 27 ayat (3): “setiap orang dengan sengaja, dan tanpa hak mendistribusikan dan/atau mentransmisikan dan/atau membuat dapat diaksesnya Informasi Elektronik dan/atau Dokumen Elektronik

\footnotetext{
${ }^{33}$ Moeljatno, Kitab Undang-Undang Hukum Pidana, (Jakarta: Bumi Aksara, 2006), hal. 42

${ }^{34}$ Diakses pada 27 Juli 2018 dari https://jdih.kominfo.go.id/pro-duk hukum/view

/id/555/t/undangundang+nomor+19+tahun+2016+tanggal+25+novem
} ber+2016 
yang memiliki muatan penghinaan dan/ atau pencemaran nama baik."

b. Pasal 28 ayat (1) dan (2): Ayat 1 "setiap orang yang dengan sengaja dan tanpa hak menyebarkan berita bohong dan menyesatkan yang mengakibatkan kerugian konsumen dalam transaksi elektornik." Ayat 2 "setiap orang dengan sengaja dan tanpa hak menyebarkan informasi yang ditujukan untuk menimbulkan rasa kebencian atau pemusuhan individu dan/atau kelompok masyarakat tertentu berdasarkan atas suku, agama, ras, dan antar golongan atau martabat palsu, dengan tipu muslihat, ataupun rangkaian kebohongan, menggerakkan orang lain untuk menyerahkan barang sesuatu kepadanya, atau supaya memberikan hutang maupun menghapuskan piutang diancam karena penipuan dengan pidana penjara paling lama empat tahun." 35

\section{Kesimpulan}

Dari uraian pada paragraph-paragraf terdahulu, dapat disimpulkan beberap hal sebagai berikut:

1. Secara umum, hoaks, yang berasal dari Bahasa Inggris "hoax" atau Bahasa Latin "hoc est corpus" berarti berita bohong atau informasi bohong yang dapat menyesatkan pihak lain, bahkan dapat menimbulkan keonaran atau permusuhan.

2. Dalam perspektif kajian Islam, hoaks dikategorikan sebagai informasi bohong yang disebarkan dengan tujuan tertentu yang dapat merugikan pihak lain. Hoaks dalam kajian Islam identic dengan peristiwa menistakan pihak lain seperti hadits al-ifk yang pernah terjadi pada periode klasik Islam yang menimpa para sahabat Nabi Muhammad saw, terutama Aisyah, isterinya tercinta. Pelakunya diancam dengan siksa yang sangat pedih di akherat.

3. Dalam perspektif Hukum Positif, hoaks merupakan informasi yang tidak bertanggung tidak bias dipertanggungjawabkan, yang dengan sengaja dan tanpa hak disebarkan oleh pelakunya yang ditujukan untuk menimbulkan rasa kebencian atau permusuhan individu dan/atau kelompok masyarakat tertentu berdasarkan atas suku, agama, ras, dan antargolongan (SARA)," Hukumannya adalah penjara setingg-tingginya sepuluh tahun.

\footnotetext{
${ }^{35}$ PAF Lamintang, Delik-delik Khusus, hal. 13
} 


\section{Daftar Pustaka}

Al-Qur'an dan Tafsir, Kementrian Agama Republik Indonesia, 2003

Abdillah, Abu, Muhammad, Al-Jami' Li Ahkam Al-Qur'an. Beirut: Dar al-Kutub al Ilmiyah, 2006.

Abdullah, Yatimin, Pengantar Studi Etika. Jakarta: PT. Raja Grafindo Persada, 2006.

Abu, Muhammad, Syuhbah, Kutub Al-Sittah, Terjemahan Ahmad Usman, Surabaya: Pustaka Progresif, 2016

Aisyah, Nur, Siddiq, Penegakan Hukum Pidana Dalam Penanggulangan Berita Palsu (Hoaks) Menurut Undang-Undang No.11 Tahun 2008 Yang Telah Dirubah Menjadi Undang-Undang No.19 Tahun 2016 Tentang Informasi Dan Transaksi Elektronik. Jurnal Lex Et Societatis Vol. V/No. 10/Des/2017.

Aji, Ahmad Mukri. "Pemberatasan Tindak Pidana Terorisme di Indonesia (Analisis Terhadap Undang-Undang Nomor 15 dan 16 Tahun 2003 Berdasarkan Teori Hukum)," dalam Jurnal Cita Hukum, Vol. 1, No. 1 (2013).

Aji, Ahmad Mukri. Urgensi Maslahat Mursalah Dalam Dialektika Pemikiran Hukum Islam, Bogor: Pustaka Pena Ilahi, 2012.

Al-Hilal, Abu Al-Asykariy, Al-Faruq Al-Lughat. Beirut: Dar al-Afaq al-Jadidat, 2011.

Al-Qasim, Abu, Muhammad bin Amr Al-Zamakhsyariy Al-Khawarismiy, AlKasysyaf'an Haqaiq al-Tanzil wa Uyun al-Aqawil. Beirut: Dar al-Ma"rifat, 2013.

Al-Sarakhsy, Syamsuddin, Al-Mabsuth. Mesir: Dar al-Fikr, 1989.

Al-Su'ud, Abiy, Tafsir al-allamat abiy Al-Su'ud IV. Libanon: Dar al-Fikr, 2017.

Al-Zyhaily, Wahbah, Al-Fiqh Al-Islamy Wa Adillatuh. Mesir: Dar al-Fikr, 1985.

Amir, Mafri, Etika Komunikasi Massa. Jakarta: PT. Logos Wacana Ilmu, 2012.

Arbi, Armawati, Dakwah dan Komunikasi. Tangerang Selatan: UIN Jakarta Press, 2006.

Asmaran, Pengantar Studi Akhlak. Jakarta: PT. Raja Grafindo Persada, 1999.

Chazawi, Adami dan Ferdian, Ardi, Tindak pidana informasi dan transaksi elektronik. Malang: Media Nusa Creative, 2015.

Chazawi, Adami, Tindak Pidana Pers. Bandung: Mandar Maju, 2015.

Chazawi, Adami. \& Ardi, Ferdian. Tindak Pidana Pemalsuan Jakarta: PT Rajagrafindo Persada, 2016.

Djatnika, Rahmat. Pengantar Studi Akhlak. Jakarta: Pustaka Panji Mas, 1996. 
Djazuli, Fiqh Jinayah. Jakarta: PT. Raja Grafindo Persada, 1996.

Dwi, Errika; Watie, Setya. "Komunikasi dan Media Sosial (Communications and Social Media)", Dosen Jurusan Ilmu Komunikasi Universitas Semarang. THE MESSENGER, Volume III, Nomor 1, Edisi Juli 2011.

Eka, Sutirman, Ardana, Jurnalistik Dakwah. Yogyakarta: Pustaka Pelajar, 1995.

Fatwa Majlis Ulama Indonesia Nomor 24 Tahun 2017 Tentang Hukum dan Pedoman Bermuamalah Melalui Media Sosial.

Hidayat Taufik, "Hukum Regulasi Media Sosial Terhadap Pengaruh Sosial Berita Hoaks ". Ilmu Widya, Vol.1 (2016).

Nugroho, Arif Sario; Fauziah, Mursid. "Polisi Dalami Motif Hoaks Tujuh Kontainer", dalam Harian Republika, Kamis, 10 Januari 2019.

Octaviyani, Putri Rosmalia. "Pembuat Hoaks Ingin Sudutkan Jokowi", dalam Harian Media Indonesia, Kamis, 10 Januari 2019.

Widyanuratika, Inas. "Pengamat: Hoaks Soal Pemilu Berbahaya", dalam Harian Republika, Jumat, 11 Januari 2019.

Yunus, Nur Rohim. Restorasi Budaya Hukum Masyarakat Indonesia, Bogor: Jurisprudence Press, 2012.

Yunus, Nur Rohim; Sholeh, Muhammad; Susilowati, Ida. "Rekontruksi Teori Partisipasi Politik Dalam Diskursus Pemikiran Politik Negara" dalam Salam; Jurnal Sosial dan Budaya Syar-i, Vol. 4, No. 3 (2017).

\section{Website.}

https://www.cnnindonesia.com/jonru-ginting jalani-sidang-perdana-kasusujaran kebencian. Artikel diakses pada 03 Juli 2018.

https://jdih.kominfo.go.id/produk hukum/view/id/555/t/undangundang+nomor+ $\underline{1} \underline{9}+$ tahun+2016+tanggal+25+november+2016

http://www.hoaks busters.org/hoaks 10

https://news.detik.com/ perjalanan -kasus - buni -yani -sampai- jaksamenuntut-2 tahun- bui. Artikel diakses pada 02 Juli 2018.

https://www.liputan6.com $>$ News > Peristiwa > Ini Posting-an Jonru Ginting yang Berujung Tersangka. Artikel diakses pada 02 Juli 2018.

http://kominfo.go.id > sorotan_media. Artikel diakses pada 02 Juli 2018.

http://www.liputan6.com > read > Asli atau Hoaks? Cek Keaslian Berita dengan 4 Cara ini. 
Supriyadi Ahmad, Husnul Hotimah

https://www.rappler.com/Indonesia/berita/151457/profil-buni-yani.Artikel diakses pada 02 Juli 2018.

http://ravii.staff.gunadarma.ac.id >files>Analisis Penyebaran Hoaks di Indonesia. 